\title{
Ю. Хao
}

\section{Методика преподавания уроков музыки в начальной школе города Чифэн (КНP)}

Статья подготовлена на основе эмпирического материала, собранного в результате посещения уроков в 4-й начальной школе города Чифэн (КНР, район Суншань) в сентябре 2019 г. Показаны специфические формы обучения детей музыкальному искусству на примере опыта проведения музыкальных занятий в китайской школе. Отдельный раздел посвящен анкетированию учащихся с целью выявлению интереса к музыкальным занятиям, а также отношения к музыкальному искусству в целом. Автором отмечаются положительные стороны метода преподавания, в то же время в результате рассмотрения и изучения представленного опыта были отмечены некоторые подходы педагогической практики, которые необходимо усовершенствовать. В статье представлены некоторые рекомендации автора. Работа является первой в цикле статей о музыкальном образовании в Китае.

Ключевые слова: начальная школа, музыкальное образование в Китае, китайская классическая флейта кукурбит, музыкальное искусство

\section{Yunwenting Hao}

\section{Research on musical classes at an elementary school of the city of Chifeng (PRC)}

The article is based on the materials collected as a result of attending classes at the fourth elementary school in Chifeng City (PRC, Songshan District) in September 2019. The author draws attention to specific forms of teaching children musical art using the experience of conducting music classes in a Chinese school. A separate section is devoted to questioning students in order to identify interest in musical studies, as well as attitudes towards musical art in general. The author notes the positive aspects of the teaching method, at the same time, as a result of reviewing and studying the presented experience, the article presents some recommendations of the author and several approaches to teaching practice that need to be improved. This paper is the first in a series of articles on music education in China.

Keywords: elementary school, music education in China, Chinese classical flute cucurbit, musical art DOI 10.30725/2619-0303-2020-1-137-140

B XVIII-XIX вB. в музыкальную культуру Китая проникают европейские традиции, которые получают еще большее распространение на рубеже XIX-XX в. В начале прошлого столетия музыкальные дисциплины вошли в обязательную программу китайских школ для учащихся младших и средних классов. В 1920-х гг. было введено повсеместное музыкальное обучение детей и подростков, что включало в себя пение, игру на музыкальных инструментах, в том числе духовых, музыкальную грамоту и сольфеджио.

Российская советская музыкальная школа оказывала большое влияние на становление профессионального музыкального образования в Китае, что выразилось в появлении в первой половине XX в. методик, специальных программ, учебников и учебных пособий для музыкального воспитания в школах. В середине XX в., когда Международным сообществом музыкального образования (ISME) были рекомендованы программы Карла Орфа и Золтана Кодаи, Китай также откликнулся на новые веяния времени.

По сегодняшний день качество преподавания музыки школьникам является важным условием в образовательном пространстве Китая. В последние десятилетия в китайскую систему образования входят более 200000 преподавателей музыки, больше 219941000 обучающихся в университетах, средних школах и начальных классах; 388 учреждений подготавливают учителей [1, с. 3-4]. Одной из основных целей музыкального просвещения и образования в Китае является воспитание гармоничной личности и в связи с этим, воспитание и обучение эстетическим нормам, этике, а также знакомство и восприятие как музыкального, так и других видов искусств.

В сентябре 2019 г. автором статьи были проведены занятия в 4-й начальной школе в районе Суншань города Чифэн во Внутренней Монголии (автономном регионе в Китае). Занятия проводились по авторской методике, созданной в Санкт-Петербургском государственном институте культуры, на основе петербургской концепции музыкального развития детей «Звуковая мозаика», в которых приняли участие двенадцать учащихся пятого класса и преподаватель Чжу Лингтун.

С самого основания школы в Чифэне в 1994 г. в учебный план были введены уроки музыки. Состав преподавателей музыки насчитывает четыре человека: два штатных педагога и два стажера, работающих полный рабочий день. Все преподаватели имеют степень бакалавра: трое из них окончили педагогическое училище в автономном регионе Внутренняя Монголия, один преподаватель по- 
лучил образование на музыкальном факультете местного университета по специальности «Гучжэн» (китайский традиционный музыкальный инструмент). После сдачи квалификационного экзамена были распределены в данную школу.

В настоящее время обучение в 4-й начальной школе составляет 6 лет. Дети, так же, как и в России, начинают учиться в 7 лет. В каждом классе проводятся два урока музыки в неделю по 45 минут. Аудитория для музыкальных занятий обычно оснащена профессиональной техникой, компьютерами, а также фортепиано, синтезатором и ударной установкой.

На каждый семестр педагогами разрабатываются соответствующие планы обучения, которые предусматривают правильное распределение нагрузки и количества занятий. К примеру, в третьем классе учащиеся осваивают одноголосное пение по пронумерованной музыкальной нотации ${ }^{1}$, а в четвертом - начинают практиковать двухголосие. Необходимо отметить, что все ученики начальных школ в Чифэне изучают и обучаются игре на музыкальных инструментах по пронумерованной музыкальной нотации (ладовой сольмизации). Традиционную нотацию в школе не преподают.

В рамках проводившегося эксперимента в программу учащихся второго класса были введены занятия на губной гармошке, в программу третьего класса - мелодика; учащиеся четвертого класса стали осваивать игру на духовом инструменте блокфлейте; в пятом классе началось обучение игре на китайской классической флейте кукурбит.

Преподаватель Чжу Лингтун в своей статье «Флейта кукурбит входит в музыкальный класс начальной школы» пишет, что в педагогической практике кукурбит может быть эффективным инструментом для стимулирования интереса учащихся к обучению и развития их музыкальной грамотности во многом благодаря таким характеристикам, как интересная форма, которая вызывает у учащихся любопытство; невысокая цена инструмента и доступность его для всех слоев населения; несложность освоения инструмента (около двух месяцев); возможность носить с собой (инструмент нетяжелый); и оригинальное звучание кукурбита, в котором отражаются древние китайские традиции. После внедрения занятий на кукурбите педагог Чжу отметила значительные улучшение знаний учащихся по теории музыки и сольфеджио [2, с. 177].

Все ученики шестого класса учатся играть на синтезаторе. Обычно учитель сам выбирает песню или музыкальное произведение в учебнике, а затем знакомит ученика с настройкой инструмента и процессом исполнения. Для закрепления материала

${ }^{1}$ Имеется в виду ладовая, относительная система сольмизации, в Китае эта специфическая система нотации называется «пронумированная». каждый ученик может взять инструмент и ноты домой и заниматься.

В каждом классе в конце учебного года проводится тест для оценки музыкальных компетенций. Существует два вида тестов: по музыкальной теории и по пению. Наивысшая оценка за экзамен 100 баллов, которые складываются из 40 баллов за теоретические знания и 60 баллов за вокал. Когда ученик оканчивает начальную школу по дисциплине «музыка», экзамена нет. Тем не менее преподаватель музыки всегда оставляет комментарии в дневниках школьников.

В последние годы во всех начальных школах в районе Суншань были введены учебники для музыкальных занятий, которые предоставляются бесплатно в начале семестра и должны быть возвращены по его окончанию. Учебники музыки содержат разнообразные материалы о музыкальных произведениях многих этнических групп Китая, а также других стран [3].

При обучении школьников пению большинство песен, отобранных преподавателями музыки, являются китайскими. Один из ведущих авторов музыкальных учебников для начальной школы Ду Юншоу писал в статье «Элементы традиционной китайской культуры в стандартном музыкальном учебнике для начальной школы», что музыкальные произведения, отражающие традиционную китайскую культуру, составляют около трети всех музыкальных композиций в учебниках [4, с. 23-24]. Китайские традиционные музыкальные произведения, несомненно, важны в обучении, так как передают особенности национальной и региональной культуры, традиционного искусства, истории, литературы и т. д. Музыкальные произведения включают народные песни, инструментальные пьесы, мелодии и сцены из кабаре, оперы и многое другое.

В качестве учебного материала для обучения педагоги используют не только школьные учебники, но и другие сборники. Эти произведения могут исполняться популярными артистами, но они обязательно должны быть рассчитаны на детей определенного возраста. На уроках музыки, помимо обучения игре на музыкальном инструменте и пению, педагоги также знакомят учащихся с музыкальными фильмами и сочинениями известных композиторов, к примеру, мюзиклом «Звуки музыки» Ричарда Роджерса и Оскара Хаммерстайна, симфонией «Из Нового Света» Антонина Дворжака и др.

В качестве примера приведем урок пения. Весь процесс заключается в том, что учитель выбирает песню, которая знакома ученикам, затем проигрывает мелодию на синтезаторе, и ученики напевают ее, используя гласные звуки или слоги. В начале каждого урока ученики сначала распеваются. После распевки выполняются ритмические упражнения, необходимые для 


\section{Методика преподавания уроков музыки в начальной школе города Чифэн (КНP)}

освоения той или иной мелодии. После того, как ученики могут правильно прочитать ритм, прохлопать в ладоши и протопать ногами, педагог знакомит школьников с мелодией песни, которую они будут изучать на этом уроке, пропевая ее и обсуждая вместе с учащимися. Далее начинается процесс изучения нот песни и затем уже ее исполнение. Когда школьники могут исполнить песню полностью, педагог работает над характером, художественным образом, динамикой исполнения. На занятиях используются также технические средства, компьютер и проектор, демонстрируется на экране танец и другие дополнительные художественные элементы, связанные с песней, для того чтобы обогатить образ. В конце урока учитель обычно подводит итоги занятия и дает домашнюю работу. По словам педагогов, учащиеся предпочитают такие варианты занятий, так как они увлекают и имеют интерактивный характер.

После посещения уроков было проведено анкетирование двенадцати учащихся 5-го класса. По результатам опроса можно сделать вывод, что абсолютное большинство учащихся интересуется музыкой и музыкальными занятиями, а их родители также проявляют интерес к достижениям своих детей. На вопрос, «обучаешься ли ты музыке, или каким образом ты получаешь основные сведения о музыке?», четверть респондентов ответили «долгое время занимаюсь музыкой в музыкальном кружке (вокал, танцы или музыкальный инструмент)». Еще четверть участвует в музыкальных мероприятиях, слушает музыку на концертах или смотрит представления, 25\% отметили учебу в школе и участие в музыкальных мероприятиях, 16\% получают знания только на уроках музыки в школе, у 9\% ответ состоял из трех пунктов - обучения в школе, занятий в кружке и участии в музыкальных мероприятиях. На вопрос, «почему тебе нравятся уроки музыки?», 66\% ответили: «Очень увлечен музыкой, хочу учиться», у остальных интерес связан с учителем музыки, возможностью отдохнуть от прочих дисциплин и нацеленностью на будущую профессиональную музыкальную деятельность. В вопросе, «что именно тебе не нравится на уроках музыки?» пятеро учащихся отметили неинтересный метод преподавания, трое ответили, что знания о музыке даются с большим трудом; четверо не могли определиться с ответом. Надо отметить, что такие категории, как «уроки музыки очень скучные» и «у меня нет интереса к музыке», никем не были выбраны. На вопрос, «что именно тебе нравится на уроках музыки?» больше всего ответов было связано с вокалом и получением эстетического наслаждения, на втором месте - с интересом к области истории музыки. Абсолютно всем учащимся нравятся изучаемые музыкальные произведения. Что касается подготовки, три четверти респондентов ответили, что смогут прочитать и пропеть ноты, для остальных это затруднительно. Половина учащихся считает уроки музыки «очень важными», для остальных - просто «важные». Согласно опросу, все занятия проводятся по расписанию в специальном музыкальном классе. В ответах на вопрос об осведомленности учащихся о проведении различных музыкальных мероприятий художественной самодеятельности половина учащихся отметила, что такие мероприятия проходят регулярно, около $40 \%$ ответили «от случая к случаю», около 10\% считает, что мероприятия проходят «нечасто». Согласно ответам двух третей респондентов, школьное радиовещание регулярно транслирует музыку, одна треть считает «от случая к случаю».

Результаты проведенной работы показывают, что 4-я начальная школа в районе Суншань придает большое значение музыкальному образованию учащихся. С первого года основания 4-й начальной школы в районе Суншань ежегодно проводится Школьный фестиваль искусств. В рамках фестиваля организованы конкурсы пения, хорового и инструментального исполнительства. В школе также есть хоры, танцевальные группы и ансамбли китайских традиционных музыкальных инструментов. Ученики этих ансамблей играют на флейте кукурбит. Школа также рекомендует успешных ребят для участия в соревнованиях, проводимых в районе Суншань или городе Чифэн. Учащиеся 4-й начальной школы неоднократно получали награды. Помимо этого, школа заинтересована в повышении компетентности педагогов и регулярно поощряет учителей в изучении новых методов обучения. Однако, по нашему мнению, если бы были улучшены следующие пункты в области педагогической деятельности, то можно было бы добиться более всестороннего развития учащихся.

Предлагаются следующие варианты:

1. В учебниках музыки, в дополнение к материалам о традиционной китайской музыке и об известных китайских музыкантах, также представлено множество известных зарубежных классических композиторов и музыкантов, их выдающиеся музыкальные произведения. Однако, учитывая, что в школе обучаются только китайские школьники, педагоги в ходе занятий более сосредоточены на преподавании патриотических песен, национальной музыки и частично академической и включают совсем небольшое количество музыкальных произведений современной музыкальной культуры. Тем не менее, начальное образование это начало профессионального развития человека и формирования его вкусов. На наш взгляд, наличие в учебной программе таких дисциплин, как «введение в зарубежную классическую музыку» и «творчество зарубежных музыкантов» позволило 
бы расширить кругозор и установить высокие стандарты музыкального искусства.

2. В связи с тем, что педагоги выбирают для занятий в основном традиционные и патриотические песни и мало времени уделяют современной популярной музыке, у учащих нет возможности познакомиться и оценить качественную популярную музыку. Это приводит к тому, что музыка, которую маленькие воспитанники слушают за стенами школы, не соответствует их возрасту, ничему не учит, часто будучи некачественной, без развитой мелодии, которая замещена одним громким звучанием. Подрастающее поколение не понимает этого и восхищается песнями не самого высокого качества.

Поэтому для улучшения качества образования школьников и защиты их психического здоровья предлагается учителям расширить представление о популярной музыке у учеников в процессе обучения. По нашему мнению, учителя могут порекомендовать качественную популярную музыку, которая несет в себе оптимизм и позитивное отношение к жизни.

3. В настоящее время все начальные школы округа Суншань города Чифэн изучают только пронумерованную музыкальную нотацию, которая относительно проста, ее действительно удобно изучать. Однако, если учащиеся знают только «пронумерованную музыкальную нотацию», им будет сложно учиться музыке в дальнейшем, потому что в современном обществе профессиональные музыканты обычно используют традиционную нотацию. У учеников школы есть возможность изучать традиционную нотацию только за пределами школы.

4. Несомненно, школьники получают качественное базовое образование, но, мы уверены, оно может быть организованно одновременно с традиционным образованием. Поэтому для повышения личностных качеств учеников будет предложена специальная техника обучения, объединяющая эти методы.

5. Общаясь с учителями, мы узнали, что в последние годы многие начальные школы в Китае включили в процесс обучения музыкальные учебники. Согласно национальному опросу 2016 г., в Китае насчитывается более 550000 начальных школ, в основном у каждого учащегося есть свой учебник музыки. Повторное использование помогает уменьшить бумажные отходы, что вносит вклад в охрану окружающей среды. Но у этой практики есть и недостатки. Каждый год в мире появляется много новых и качественных музыкальных произведений. Соответственно, музыкальные учебники должны обновляться каждые несколько лет. Период обучения в начальной школе в Китае составляет 5-6 лет. Если учебник музыки используется снова, тогда содержание музыкальных учебников остается более 10 лет без обновления. В этом случае учащиеся не могут изучать новый современный музыкальный материал и узнавать новые музыкальные идеи. В этом нет пользы для последующего развития учащихся. Хотелось бы, чтобы китайский национальный сектор образования более часто обновлял учебники музыки, которые попрежнему могут содержать музыку и песни многих этнических групп Китая, а также других стран. Эта часть может оставаться неизменной. В то же время учителям музыки необходимо обращать внимание на новые музыкальные произведения, которые появляются каждый год. Следовательно, учебники можно дополнить слайд-шоу, чтобы познакомить школьников с новыми прекрасными музыкальными произведениями. С одной стороны, это позволит избежать траты бумаги, с другой даст возможность познакомиться с современной музыкой и новыми музыкальными идеями.

Это лишь самые общие рекомендации, которые возникли в процессе изучения опыта работы музыкальных педагогов в китайских школах. В настоящее время автором разрабатывается специальная методика по эстетическому развитию детей и профессиональному обучению музыке в китайских школах на основе вышеназванной СанктПетербургской концепции «Звуковая мозаика», которая была создана Е. Л. Рыбаковой в 1990-е гг. в Санкт-Петербургском государственном институте культуре и представлена на конгрессах ISME в 1994, 1996 гг. Материалы этой методики будут представлены в следующих статьях.

\section{Список литературы}

1. Фан Цзуин, Цзи Джиаксин. Статус-кво и перспективы музыкального образования на основе музыкального разнообразия в материковом Китае. Пекин: Китайская консерватория, 2008. 16 с.

2. Джу Лингтон. Обучение инструменту кукурбит в начальной школе. Чанджун: Экзам викли, 2012. 196 с. (Кит. яз.).

3. Музыка (Цифровой метод обучения). Пекин: тип. нар. образования, 2012.59 с. (Кит. яз.).

4. Ду Йонгшоу. Элементы китайской традиционной культуры в учебниках начальной школы. Сиань: Музыка мира, 2008. 65 с. (Кит. яз.).

\section{References}

1. Fan Zuyin, Xie Jiaxing. The status quo and prospect of music education based on musical diversity in Mainland China. [Beijing]: China Conservatory, 2008. 16.

2. Zhu Lingtong. Let hulusi into primary school music classes. Changchun: Exam Weekly, 2012. 196.

3. Music (Numbered musical notation). Beijing, 2012. 59.

4. Du Yongshou. Elements of Chinese traditional culture in primary music textbooks. Xian: Music World, 2008. 65. 